\title{
Precision Radiation
}

Oncology 



\title{
Precision Radiation Oncology
}

\author{
Edited by Bruce G. Haffty \\ and Sharad Goyal
}

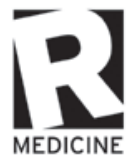

Rutgers University Press Medicine

New Brunswick, Camden, and Newark, New Jersey, and London 
A Cataloging-in-Publication record for this book is available from the Library of Congress.

A British Cataloging-in-Publication record for this book is available from the British Library.

978-0-8135-8596-3

$978-0-8135-9254-1$

$978-0-8135-9255-8$

978-0-8135-9256-5

This collection copyright (C) 2018 by Rutgers, The State University

Individual chapters copyright (C) 2018 in the names of their authors

All rights reserved

No part of this book may be reproduced or utilized in any form or by any means, electronic or mechanical, or by any information storage and retrieval system, without written permission from the publisher. Please contact Rutgers University Press, 106 Somerset Street, New Brunswick, NJ 08901. The only exception to this prohibition is "fair use" as defined by U.S. copyright law.

The paper used in this publication meets the requirements of the American National Standard for Information Sciences-Permanence of Paper for Printed Library Materials, ANSI Z39.48-1992.

www.rutgersuniversitypress.org

Manufactured in the United States of America 